\title{
THE EXODUS AND IDENTITY FORMATION IN VIEW OF THE YORUBA ORIGIN AND MIGRATION NARRATIVES ${ }^{1}$
}

\author{
Funlola Olojede \\ Old and New Testament \\ Stellenbosch University
}

The past is but the beginning of a beginning (HG Wells)

\begin{abstract}
Certain elements of the origin and migration narratives of the Yoruba such as a common ancestor, common ancestral home, common belief in the Supreme Deity provide a basis for identity formation and recognition among the people. It is argued that the narratives help to bring to light the memories of the Exodus and Israel's recollection of Yahweh as the root of its identity. The juxtaposition of cosmogonic myths and migration theories foregrounds the elements of identity formation of the Yoruba people and have a parallel in the blending of both cosmic and migration elements in Exodus 14-15:18. This blending also points out clearly the role of Yahweh as the main character in the Sea event.
\end{abstract}

Key Words: Exodus, Identity, Migration, Yahweh, Yorùbá

\section{Introduction}

The hypothesis is that Yorùbá traditions of origin and migration influence the process of identity formation in certain ways and that this implication for identity may contain certain heuristic values that can be used to interpret the exodus in a contextual way. In what follows, a literature review of basic cosmogonic myths and migration theories of the Yorùbá is carried out to determine their impact on the people's identity formation. This is followed by a brief literary consideration of the Sea event (Exod 14-15) which is a two-way prosaic and poetic rendition of the sea crossing by the children of Israel after their departure from Egypt. The study will attempt to show that Israel's identity is marked by the event at the Sea with Yahweh the dominant role player at the centre of that identity.

Social scientists have noted that certain parameters help to define individual or group identity. These parameters include religion, nationalism, ethnicity and language. They constitute in part or in whole, some of the processes involved in identity formation (Capozza \& Brown 2000; Castells 2004). Studies have, however, shown that the parameters for defining identity are in a sense open-ended and context-based (Olojede 2008:8). The origin migration narratives will therefore be considered in the light of the elements of identity formation. 


\section{Yorùbá Origin/Migration and Identity}

\section{Origin Narratives - Divine Origin}

According to an oral tradition, ${ }^{2}$ Olódùmarè the Supreme Deity in Yorùbá belief, resided in heaven, and below was a watery surface. He then sent his right hand man, Obàtálá the god of purity or morality with a snail shell (or a napkin in other accounts) filled with loose earth, a hen (some traditions say it is a rooster) and a pigeon. ${ }^{3}$ On arrival, Obàtála poured out the sand while the hen and the pigeon spread it with their claws on the watery surface so that land appeared. A chameleon was then sent to inspect the work and it brought back a report to Olódùmarè that the earth was wide enough, Ile-Ifẹ or the place of spreading. The place where this took place thus became known as Ilé-Ife (or Ife), the centre of creation from where human beings, and the Yorùbá, in particular began their dispersal. Later, Obàtálá was sent back with Ơuńnmilà, another òrì à, to equip the earth. As part of his task, Obàtálá was to mould human bodies from clay and present them to Olódùmarè to breathe life into the finished forms. For this role, he is known as 'the sculptor divinity' (Idowu 1962:21). After moulding the lifeless bodies, he would store them in a place pending the time Olódùmarè would come and breathe into them (cf. Bowen 1968:314).

From this point however, traditions diverge in details. An Ife tradition claims that Obàtálá was a lover of palm wine and he used to drink to the point of intoxication. On his way to carry out Olódùmarè's instruction, he was so drunk that he fell into a stupor. When he delayed, as he would not wake up on time from his drunken sleep, Odùdùwà was sent to investigate what had gone wrong. Finding Obàtálá in deep sleep, Odùdùwà collected his equipment for forming human bodies and just went ahead and fulfilled the task himself thereby supplanting Obàtála and becoming the creator of solid earth in the place of Obàtálá (cf. Idowu 1962:22; Awolalu 1979:13). ${ }^{4}$

In short, Yorùbá mythology insinuates that the people were the first of God's creation and that the dispersal of human beings began at Ilé-Ifẹ. Their ancestor, Odùdùwà (Obàtálá or Orúnmilà in some traditions) also descended from God.

\section{Migration Narratives}

The various theories in answer to the question, "Where do the Yorùbá come from?" may be summarized into four:

\section{- 'The Yorùbá came from Mecca'}

The tradition that the Yorùbá came from Mecca is expounded in Samuel Johnson's work, The History of the Yorubas, which has become a reference point for subsequent works on Yorùbá history. In the study, the story is told of Lámúrudu, a king of Mecca whose

2 This tradition is recorded by Idowu (1962:18-21; see also Awolalu 1979). Since most of the narratives on origin and migration are based largely on oral tradition, the written sources consulted in this study are inevitably early.

3 Some writers recount that Olódùmarè let him down from heaven with a long chain (cf. Lloyd 1955:21).

4 Another tradition claims that while Obàtálá was drunk, he started creating misshapen human bodies and it was from these albinos, and other deformed persons such as the lame, the blind, dwarfs, and hunchbacks were formed. These are all considered sacred to Ọbàtá and are called ẹi òrì à, that is, those consecrated to the deity (cf. Awolalu 1979:21; Drewal et al 1989:44). They are his special devotees and priests and are not to be despised because they also are the products of the sculptor divinity (cf. Babatunde 1992:60). 
descendants were Odùdùwà, the ancestor of the Yorùbá and the kings of Gogobiri (that is Gobir in Hausaland) and of Kukawa (in Bornu), both of which are in the north of Nigeria. The period of Lámúrudu's reign is presumed to be after the arrival of Islam. Johnson records the account as related to him and is worth quoting here:

The Crown Prince Odùdùwà relapsed into idolatry during his father's reign, and as he was possessed of great influence, he drew many after him. His purpose was to transform the state religion into paganism, and hence he converted the great mosque of the city into an idol temple...

The narration further states that Asara, Oduduwa's priest had a son called Braima. When Braima grew older, one day in the absence of his father, he used an axe to destroy all the idols and the images that were desecrating the mosque. When this act was discovered, the people ordered that Braima be burnt alive. This resulted in a civil uprising in which the Mohammedans gained the upper hand and subjugated their opponents. Subsequently:

Lámúrudu the King was slain, and all his children with those who sympathized with them were expelled from the town... Odùdùwà [and his children] ... travelled 90 days from Mecca and after wandering about finally settled at Ile-Ife where he met Agboniregun (or ẹtilu) the founder of the Ifá worship (Johnson 1921:4).

This tradition details the account of how Odùdùwà, a supposed prince of Mecca, escaped with his men after a religious uprising and migrated to Ilé-Ifẹ. From the account, it can be inferred that Ilé-Ifẹ was already inhabited at the time of their arrival. Therefore, Odùdùwà became the progenitor of the Yorùbá people, according to this tradition.

In his comments on this piece of tradition, Johnson (1921:5) argues that it is improbable that the Yorùbá came from Mecca because "no such accounts as the above are to be found in the records of Arabian writers of any kings of Mecca; an event of such importance could hardly have passed unnoticed by their historians". Moreover, Beier (1955b:19-20) mentions that in many smaller Yorùbá towns, several versions of this story do not claim an origin from Mecca but a migration of Odùdùwà and his men from beyond a great river. He further remarks that, "It is not uncommon for people to link up their history with some other place of renown" and that "it was possible that the Yoruba drummers telling the story of Odùdùwà added the name Mecca to their story, after Mecca had become a place of legendary fame through Yoruba pilgrims who had returned from that town".

Taking a cue from Beier, Law (1973:30) notes that, "the claim to origin from Mecca is not an original element of the tradition, but a later elaboration, intended to link the Yoruba to the prestigious civilizations of the east" (cf. 1977:28-9). Overall, the theory that the Yorùbá must have migrated from Mecca to Ilé-Ifẹ has met with disapproval among scholars.

\section{- 'The Yorùbá came from Egypt'}

A major exponent of the theory is Olumide Lucas whose 400 page Oxford doctoral dissertation, The Religion of the Yoruba (1948), is wholly devoted to the task of tracing a connection between the Yorùbá and Egypt. His main thesis is that the Yorùbá must have resided in ancient Egypt for a long time before moving to their present location, and that origin accounts for the similarities between the Yorùbá and ancient Egypt. The theory is not based on oral tradition per se, but on pieces of evidence from written documents, which he uses to develop his argument.

Using a kind of folk etymology, first, he argues for a Yorùbá connection with Egypt based on what he refers to as similarity or identity of language (1948:18-20). He alleges 
that fifty percent of Yorùbá vocabulary is of Egyptian origin or root and to illustrate his point, he considers words from five short paragraphs that he claims were randomly selected from some Yorùbá literature. His conclusion is that at least half of the words in the passages are "survivals of Ancient Egyptian words" (1948:343).

Lucas' second point is that the Egyptian connection is based on similarity or identity of religious beliefs and the third argument, which is similar to the second, is similarity or identity of religious ideas and practices. According to him, some of these similarities include the names and attributes of the gods of both peoples, belief in life and judgement after death, deification of kings and the belief in guardian spirits (1948:20-26). In other words, Yorùbá religion is a survival of ancient Egyptian religion and it stands in genetic relation to the latter (1948:344). Finally, he argues that a connection can be established based on survival of customs, and names of persons, places, objects, etc. (1948:26-30). These include among other things, elements of ancient Egyptian hieroglyphics, emblems and other symbols in Yorùbá (especially, Ifẹ) art and craft.

However, Lucas is not alone. Before him was Talbot (1926) and even Johnson, who after disputing the Mecca theory, argues that the Yorùbá probably emigrated from Upper Egypt to Ilé-Ifẹ. His evidence includes the sculptures known as Ife marbles and the 'Phoenician' characters on Opá Orànmíyàn, an ancient granite obelisk over $18 \mathrm{ft}$ high at Ife (Johnson 1921:6). At any rate, the Egypt theory has not been established clearly as authentic since several scholars maintain that the widespread story of an Egyptian ancestry cannot be credited (Wescott 1957:10-15).

\section{- 'The Yorùbá came from the Northeast of Africa'}

As the two theories of Meccan and Egyptian origin became increasingly unpopular, a third position, which is not unrelated to them and which is not so specific, gained more ground. This is the theory that the Yorùbá came from the north eastern part of Africa. This theory might have been triggered by two different written accounts, a work originally written in Arabic in 1812 by Sultan Muhammad Bello of Sokoto (1779-1837), the grandson of Uthman dan Fodio, the founder of the Fulani Empire and the Sokoto Caliphate, and Leo Frobenius' account in The Voice of Africa (1913).

Bello's writing was obtained by Clapperton and his travel companion, Denham and a part of it is an account of what was purported to be the origin of the Yorùbá, whom Bello referred to as Yarba. Bello's account of Yorùbá migration, which has been regarded as fanciful erroneous and mere hearsay (Lucas 1948:16; Law 1977:15), states that the Yorùbá are descendants of Nimrod who were driven out of Arabia (or Iraq) to West Africa through Sudan. In essence, Bello records a Middle East origin and a migration through the Sudan for the Yorùbá.

In 1910-11, the German professor of anthropology, Leo Frobenius was at Ilé-Ifẹ on expedition and conducted excavations on some sites. His report on the excavations drew world attention to the historical and archaeological significance of Ifẹ. The sophistication and the naturalism of the artwork excavated at Ife made Frobenius (1913:345) conclude that he had discovered the survival of an ancient West Mediterranean colony on Africa's Atlantic coast:

I maintain I have re-discovered Atlantis, the Emporium of the culture of the West on the further sides of the straits of Gibraltar, that Atlantis, whose walls, as Solon informs us, held within them Poseidon's Castle, where there was a wealth of luxuriant vegetation... I lay claim to Yoruba, so tropically lush and rank in its vegetation... this Yoruba, I assert, 
is Atlantis, the home of Poseidon's posterity, the Sea-God by them named Olókun; the land of a people whom Solon declared: They have even extended their lordship over Egypt and Tyrrhene!

Frobenius' hypothesis is that there must have been some Etruscan influence on the Atlantic coast in the thirteenth century BC the relics of which he found at Ilé-Ifẹ. The people must have got to the west coast by way of the sea through fleets from North Africa and the remains of that Mediterranean culture can be found in different aspects of Yorùbá art and culture such as the use of the handloom, the bow and arrow, and drums with a distinctive North African imprint. Others include the construction of water storage and of houses with ridge roofs as in North Africa.

The hypothesis has been considered untenable and a guess, not only in archaeological circle but also in historical and religious. However, it should be noted that there is often confusion between the locations, northeast of Africa and Middle East in the accounts and references are sometimes vague. Adetugbo (1973:182) states that, "The belief that is current among the Yorùbá is that they migrated to their present home from somewhere in the Middle East or Lower Egypt in different waves between the seventh and eleventh centuries A.D." It is generally an either/or situation (e.g. Johnson's Egypt/Nubia and Biobaku's Egypt/beyond theories).

In addition to this, various other traditions claim that the Yorùbá originated from the east of the Niger (cf. Bowen 1968:266), from the Sudan, parts of Asia (cf. Lucas 1948:15), from across a big river (Beier 1955b:19) or from a far country (Farrow 1926:21). Beier (1955a:26) also attempts to prove that the Nupe country was one of the stages of the Yorùbá migration.

\section{- 'The Yorùbá and the exodus from Ilé-Ife'}

The inference from the above theories is that there must have been a Yorùbá migration from an unconfirmed location north of the Sudan. Oral traditions also fully support the idea of a migration. However, a secondary and internal migration, subsequent to that original migration has additionally been posited. This secondary migration took place from Ilé-Ifẹ.

We have noted from the mythical accounts that Odùdùwà, the progenitor of the people, arrived from heaven. However, various traditions regard Odùdùwà as a mortal man and the leader of a group of people who arrived at Ifẹ. In an account by Johnson, Odùdùwà's eldest son was Okànbí, who in turn had seven sons out of whom the tribes of the Yorùbá sprang up. The princes dispersed, founded their own kingdoms, that is, different Yorùbá towns and wore beaded crowns. In other words, a secondary migration took place after Oduduwa's death, possibly in waves in which the people were dispersed to different parts of the present Yorùbáland. The account further relates that there were people (aborigines) at Ife when Odùdùwà arrived there with his group who must have been conquered and assimilated by Odùdùwà's troupe (Johnson 1921:15).

Several variants of this tradition also exist, but they all seem to agree that there were aborigines in the land when the migrants arrived (cf. Beier 1955a:25; Idowu 1962:63; Law 1973:31). Some traditions identify these aborigines as the Ugbos or Igbos, ${ }^{5}$ who were at war with Ifẹ for a long time and now dwell in the Ilaje district in Òndó State (cf. Awolalu 1979:26). The presence of an aboriginal population is supported by archaeology. For

The Ugbo should not to be confused with Igbo/Ibo, a major Nigerian group. 
example, radiocarbon dates show that Ife was occupied as early as $500 \mathrm{AD}$ whereas the original migration has been dated much later (c.10th century AD).

Summary of the cosmogonic myths and the migration theories:

- Olódùmarè, the Supreme Deity is the author of creation.

- Creation of both the earth and its inhabitants occurred at Ilé-Ifẹ.

- The primary agent of creation was one of Olódùmarè's òrì à (ministers) who was let down from heaven by Olódùmarè, and this was either Obàtálá or Odùdùwà.

- The Yorùbá were immigrants from a location that is subject to controversy outside their present homeland.

- This point of migration could have been Mecca, Egypt, the Sudan or northeastern part of Africa but the migration primarily took the people to Ilé-Ifẹ.

- The leader of this troupe was Odùdùwà who is recognized as the people's progenitor.

- There were aborigines at Ifẹ, who were either conquered or assimilated when the migrants arrived.

- A secondary or internal migration took place after the death of Odùdùwà, which resulted in their founding of other Yorùbá kingdoms and towns.

- These towns and cities commonly trace their descent to Ilé-Ifẹ, regarded as their ancestral home.

From the foregoing discussion, it can be inferred that the Yorùbá account for their origin both from the perspective of cosmogony and of the migration traditions. The two perspectives point to Ile-Ifẹ and to Odùdùwà as rallying points for the people. We have noted at the onset that certain parameters such as religion, nationalism, ethnicity and language are used to define identity. Karin Barber has also remarked that, "origin is the foundation of identity" (1991:136). Thus, for the Yorùbá, who speak a common language (with many variants), the traditions of common origin function as a symbol of identity and the two elements common to the traditions of origin and the migration theories above are Ile-Ife and Odùdùwà.

There is not only a clear mythical but emotional, historical and religious attachment to Ilé-Ifẹ among the Yorùbá. However, from available data, it is reasonable to conclude that for the Yorùbá, it is not affinity with an indeterminate point of departure (Mecca, Egypt, Sudan or northeast Africa) that defines his or her identity in terms of origin, but the ancient attachment to Ifẹ, the place of a 'second exodus' of the people. It is not an attachment to that place of long ago, of which nothing is remembered in the collective consciousness of the people but to this latter place, a physical entity they can identify with and revisit.

On the subject of Odùdùwà, there is no doubt that he remains a symbol of identity among the people. His name is used in different contexts in which the Yorùbá seek to distinguish themselves from their neighbours, especially in matters of politics and ethnicity. In such situations, the Yorùbá come out boldly to identify themselves as 'Omo Odùdùwà' (the descendants/offspring of Odùdùwà).

For the Yorùbá therefore a common language, a common ancestor and a common place of origin entrenched in common myths of origin and migration, constitute the principal elements in the process of identity construction. 


\section{The Exodus and Identity Based on Exodus 14-15 (The Sea Crossing/Song of the Sea)}

The combination of Exodus 14 and Exodus 15:1-21 in the history of interpretation is what is referred to as the Sea event with chapter 14 known as the Sea Crossing and chapter 15:121 called the Song of the Sea (Fretheim 1990:152). The choice of Exodus 14 and 15:21 in this study is thus informed primarily by two factors. The first is that the Sea event has been considered the 'heart' of the exodus tradition and was annually rehearsed as part of the exodus story in the Passover ritual (cf. Childs 1970:406-407; 1977:221, 223). Likewise, Dozeman (1996:153) asserts that, "The Song of the Sea is the cornerstone of any traditionhistorical study of the exodus, and indeed, of the Pentateuch in general". 6

\section{Exegetical Consideration of the Sea Event}

With Exodus 14, the narrative account of the Sea Event, we have a series of events that began in 13:16-22 with the flight of the children of Israel from Egypt, their pursuit by their erstwhile taskmasters, their desperation on sighting their pursuers and the miraculous parting of the sea that spelt deliverance for Israel and doom for the Egyptian army. The first verse of chapter 15 therefore continues the narrative with the first line but changes into a song of triumph and celebration which the narrator attributed to Moses, to the people of Israel and to Miriam. In contrast to the prose account of 13:16-14:31, the Song of the Sea,

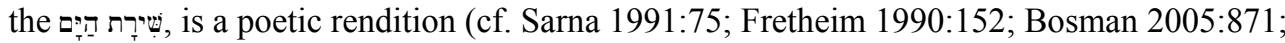
Olson 2010:32-33). Olson (2010: 33) points out that it has been noted that the overriding theme of the Song of the Sea is pilgrimage.

Although it is easy to consider the שִׁירָ as the poetic version of the prose account of chapter 14, Sarna (1991:75) cautions that this could be misleading as the Song takes for granted that the reader is already acquainted with some facts in the prose account and therefore they bear no repetition. Yahweh had just miraculously delivered his people from the host of Pharaoh in a historic move that silenced the enemy forever. It was time for the people of Israel and their leader to sing a song of victory and of thanksgiving unto Yahweh their saviour. The song is then introduced as a personal testimony (cf. Houtman 1996:227) in grateful response to Yahweh's great acts. Fischer and Markl consider the song and the attendance prayer and dance in Exodus 15 as the first cry of the newly born nation of Israel, the same way that a newborn baby cries when he leaves the lap of his mother. ${ }^{7}$

The rendition in ch. 15 takes a different twist in vv. 19-20 recalling once again the victory over Pharaoh's army but by the mouth of Miriam mentioned in the introduction to the poem as the one who led the women in singing and dancing with her tambourine (or hand-drum) in her hand. Several interesting comments have been made about this last bit of the שִׁירָ. Houtman (1996:293-4) regards V. 19 as a later addition that is repeated for emphasis and that in Israel, women often sang the victory songs after a battle was won (cf. Judg 5:1; 1 Sam 19:35). This observation has led some scholars to conclude that the entire Song of the Sea was in fact Miriam's song (cf. Sarna 1991:82; Janzen 1992:211-220). Janzen (1992:216) contends that Miriam actually led the whole congregation in the singing

6 See Olojede (2008) for a detailed close reading of both Exodus 14 and Exodus 15 from a literary perspective, in particular, from the point of view of characterization.

$7 \quad$ "Wenn ein Kind bei der Geburt den Schoß der Mutter verlässt, schreit es. Der erste Schrei des neugeborenen Israel ist das Lied am Schilfmeer in Ex 15. Darin erhebt sich das Volk über sein (An-)Klagen und Schweigen im Kapitel zuvor hinaus zu gemeinsamem Gebet, zu Gesang und Tanz - alle drei Elemente kommen hier erstmalig innerhalb der Bibel vor" (Fischer \& Markl 2009:165). 
and that the opening line of the Song of the Sea, "I will sing", was in fact a response to Miriam's command, 'Sing!' which opens v. 21. He explains that the fact that Miriam's song came after the main song was a result of a narrative technique called analepsis that temporarily withholds some information and introduces it later to create a literary effect (1991:214).

Another view is that the שִירָ was sung antiphonally; Moses led the men and Miriam led the women in the singing (cf. Sarna 1991:76; Alter 2004:402; Dozeman 2009:331, 341) ${ }^{8}$. On this point, Zornberg (2001:219) notes that, "Indeed, the women's separate song casts a shadow of ambiguity back over the first song, song by the Israelites" as it suggests that only males sang the first song. She also adds that the text describes Miriam as responding to the men, that is, לָ לה (them) as opposed to a response to women, לָה in v. 21. For Zornberg (2001:7-8) whose reflections on the Exodus are from a Midrashic perspective, the omission or lack of specific interest in the feminine in the text ${ }^{9}$ is redressed in Midrashic comments. She claims that in the Midrash, "women figure as having a separate, hidden history. In effect, the Midrash makes the reader aware of a mistaken reading: all along, women have been really absent, really elsewhere" (2001:9). Zornberg therefore advocates for an alternative history, the Midrashic history of women.

From a narratological perspective, Exodus 14 and Exodus 15:1-21 exhibit certain similarities and dissimilarities. Houtman $(1996: 243 ; 244)$ observes some similarities in terms of terminology (even though the Song demonstrates some other terminological and orthographical distinctiveness which it does not share with other parts of the book of Exodus). Patterson (2004:49) affirms that there is an essential unity in the two accounts "in several matters of theme and vocabulary". For instance, both accounts relate that the Egyptians perished in the sea and that the waters piled up on either sides of the seabed. An obvious dissimilarity between the prose and the poetry accounts is that the latter makes no clear mention of Israel crossing the ים- B. By contrast, a unique feature of the prose account is the claim that the Israelites walked on dry ground through the parted sea (cf. Patterson 2004:50).

That Exodus 14 is a narrative without question but the poetry of chapter 15 is also set in a narrative context with Exodus 15:1a acting as a prosaic prologue to the poem. ${ }^{10}$ Verses 19 and 20-21a are equally prosaic with vv. 20-21a serving as an introduction to Miriam's Song.

Taken in its narrative sense therefore, we shall examine a particular narrative feature that is common to both the prose and poetry accounts and crucial to our discussion, that is, the characters. To begin, four main characters are attested in the text. These are Yahweh, Moses, the children of Israel and Pharaoh, in the order in which they are first encountered in the narrative (Exod 14:1-3). In the Hebrew Bible, the word Exodus 14 and 13 times in Exodus 15:1-21 while ישְרָאָל occurs 17 times in chapter 14 and

8 Dozeman (2009:331) offers an interesting remark on the function of the Song of Miriam as an antiphonal response to the Song of Moses. He claims that, "The two victory songs represent distinct interpretations of the exodus. The Song of the Sea interprets salvation as an exodus and a conquest... The Song of Miriam anticipates neither the wilderness journey nor the conquest of the land of Canaan. Her celebration of salvation is limited to Egypt and the destruction of the army in the sea".

9 Some scholars claim that in this text, Miriam and other women are portrayed as playing secondary roles to Moses (cf. Steinberg 2010:169-170).

10 Dozeman (2009:32) regards the song as a response to the narrated events in Exodus 14. He further notes that 15:19-21a "is a narrative, which separates the Song of the Sea (15:1b-18) and the Song of Miriam (15:21b)". 
twice in chapter 15:1-21. The word מש: occurs 7 times in Exodus 14 and once in chapter 15 while פַּרע occurs 7 times in chapter 14 and twice in chapter 15:1-21.

Propp (1999:32) asserts that Exodus has three heroes - Moses, Israel and Yahweh and to some extent, we consider this valid. However, we would add that Exodus (by extension chapters 14-15) also has an anti-hero, that is, Pharaoh. Pharaoh carried out one good deed in his entire career - he let Israel go (Exod 13:17)! Regrettably, he was not renowned for this act. Rather, he is most remembered for his legendary stubbornness and his ultimate defeat in the heart of the sea when he chose to pursue Israel instead of submitting to Yahweh's wish.

Israel was a target, a target of both Pharaoh and of Yahweh. To Pharaoh, Israel was an object of slavery but to Yahweh, Israel was a candidate of redemption, a people he could call his very own. Having just escaped from the hand of Pharaoh, they suddenly discovered that their ordeal was not yet over. In their despair, they cried (Exod 14:10). Who would have thought that their crying was not yet over! In Egypt, they cried (Exod 2:23; 6:5) and even after the mighty escape, their fountain of tears would not dry. Their being caught literally between the devil and the deep blue sea simply demonstrated the turmoil and the desperation that characterised Israel's story. For these people, there seemed to be no respite. Was Israel a pawn, a pawn in the hands of two masterful players?

As for Moses, even though his name was not mentioned in the שִירָה except in its narrative introduction, that he played a pivotal role in the Sea event is evident from the account of chapter 14. Moses was Yahweh's representative to his people. He took instructions from Yahweh's mouth to the people $(14: 1,15)$ in his capacity as a prophet. However, we also see him performing a pastoral role, assuring the people of Yahweh's deliverance and allaying their fears even when they turned against him and blamed him for their woes (14:11-14).

Moreover, Moses was commanded to lift up his rod and stretch his hand over the sea to divide it (14:16) in preparation for Yahweh's move (14:21). Again, Moses stretched out his hand in response to Yahweh's command so that the water returned (14:26-7). It is baffling to discover that for all of Moses' effort, he received no credit. The hand that Moses stretched out was only cosmetic, the rod that he raised a mere sign. The שִירָ reveals that it was indeed Yahweh's hand, his right hand, that was stretched over the sea (15:12; cf. Propp 1999:497). What is more, apart from a single mention of Moses' name in the narrative introduction of the שיריה, his name is not at all mentioned in the song as a partner in the miraculous deliverance. This fact has not escaped the notice of scholars (cf. Child's 1977:249; Fretheim 1990:163; Sarna 1991:75; Janzen 1992:213; Propp 1999:485; Dever 2001:235). It is not surprising therefore that Moses was later described as more humble than all the men on the face of the earth (Num 12:3). He had no reservation about giving all the credit and glory to God.

The last character to be considered is Yahweh. We have noted that the name Yahweh appears a total of 29 times $^{11}$ in the text - 16 times in chapter 14 and 13 times in chapter 15:1-21. Propp (1999:509) notes that, "Yahweh is the Song's dominant word..." He also remarks that, "In addition to the divine name, the Song's major theme is Yahweh's 'hand, arm', mentioned five times with varying terms..." (1999:529). In our view, this recurrence seems to underscore the importance that the narrator places on the role of the character. Yahweh is at the centre of the whole event as the song clearly suggests. All that happened

11 This occurrence does not include the abbreviated form of YHWH, Yah in 15:2 or Adonai in 15:17, for instance. 
at the Sea revolves around Yahweh even though his actions have an effect upon Israel who is the object of the deliverance.

The Song appears more focused on Yahweh than the narrative does. As Sarna (1991:75) shows, while in the narrative there are some other intermediaries between Israel and Yahweh, such as the angel of Yahweh, the cloud, darkness and Moses, "by contrast, the 'Song at the Sea' celebrates God's direct, unmediated, personal incursion into the world of humankind". The author further notes that its dominant God-centred theme distinguishes the שִּירה from its narrative analogue (1991:76). Similarly, Dozeman (2009:329) who separates the Song of Moses from the Song of Miriam admits that both songs "focus exclusively on Yahweh". We shall consider some of Yahweh's role below:

- To begin with, the narrative opens with Yahweh who instructed Moses to give direction to the children of Israel concerning their journey $(14: 1-2$; cf. 14:15, 26). Yahweh guides his people (cf. Durham 1987:187).

- Yahweh claimed he would harden Pharaoh's heart $(14: 4,17)$ and he actually did (14:8).

- When the children of Israel became afraid, to Yahweh they cried (14:10) and he responded (14:15).

- To assure this distressed people, Moses made them aware that Yahweh had a plan (Child's 1977:226) - it was to fight for them and to save them (14:13-4). To show that he meant to carry out that plan, he had sent his angel ahead of them (14:19).

- Yahweh then drove the sea apart even though Moses stretched forth his hand over it (14:21). The שִ gives further details of this, noting that the sea parting was accomplished by the breath of Yahweh's nostrils (15:8).

- Yahweh looked down on and troubled the Egyptian army (14:24).

- Yahweh overthrew the Egyptian army in the midst of the sea, causing both the chariots and the riders to drown $(14: 27-8 ; 15: 1,4-5,10,12,19,21)$. Houtman $(1996: 238)$ comments that, "Only Yahweh engages the Egyptians in battle. Israel has no part in it, not even in the pursuit of the enemies".

- Yahweh saved Israel (14:30; cf. Durham 1987:197).

From the foregoing, it can be inferred without a doubt that Yahweh is the main character ${ }^{12}$ at the Sea (cf. Patterson 2004:46). Yahweh was the hero of the battle as Weitzman (1997:26) correctly observes but we would add that he was indeed the hero of the entire Sea event. Even later allusions to the Sea event in the Hebrew Bible affirm that it was Yahweh who acted on Israel's favour to accomplish the victory at the Sea (cf. Josh 2:10; Neh 9:911; Pss 74; 106:9-12; 136:13; Isa 43:16-19; 51:10; 63:11-13, etc.). Fretheim (1990:164) remarks that, "What God has done reverberates throughout the earth, calling attention to this God's identity". More specifically, he argues that, "the song insists that the Creator God is the decisive factor in the event" (Fretheim 1990:165). This assertion echoes Durham's (1987:196) claim that, "this event is set up, managed, and brought to its dramatic conclusion by Yahweh... Even the Egyptians are reported to have taken the point".

12 Amit (2001:88) points out that, "There are four criteria to help us determine who is the leading character in any given work of literature: one, the focus of interest; two, quantitative; three, structural; and four, thematic". Clearly, these four criteria could be identified with Yahweh's role in the Sea Event examined above. 


\section{Israel's Identity}

In addition to ancestors, the Torah and land, Israel's identity has been associated variously with the covenant with Abraham, with circumcision (Pohl 1999:138; Foerster 1964:141) or even with the Sabbath (Foerster 1964:145). Lemche (1998:51) goes as far as stating that "Moses' role as catalyst decides Israel's peculiar self-identity".

In terms of the event, the act of crossing the ים- carved out a new identity for Israel (cf. Ashby 1998:17). As long as Israel remained in Egypt, the identity could only be that of a slave. The crossing of the river marked for Israel therefore the beginning of a new identity. Houtman (1996:232) affirms that, "For Israel, the crossing was the transition to a new existence". To buttress this view, Dillard's comment that "the exodus deliverance was one that helped mould Israel's self-understanding that they were God's people" is also noteworthy (1994:66).

In connection with the major characters or role players in Exodus 14-15:21, some remarkable points have also been observed. Although Pharaoh, Moses and Israel are important characters in the text, the main character and the (super) hero is Yahweh. This primacy or supremacy of Yahweh is reflected throughout the book of Exodus. The move to deliver Israel from the house of bondage was at Yahweh's instance (Exod 3:7-8) and all the mighty acts done in Egypt by the hands of Moses and Aaron were at Yahweh's instructions. According to Gowan (1994:2-3), apart from Exodus 1-2 in which there is no mention of God or what God is doing, in the rest of the book of Exodus, "God is depicted as the dominant figure" and is both vocal and active throughout the book. Besides, the major theological themes in the book such as Liberation, Law, Covenant and Presence (cf. Brueggemann 2005:5-6) are all profoundly connected to Yahweh in one way or the other. Yahweh is the deliverer but he is also the lawgiver. He is the God of the covenant with the fathers and the one who manifests his presence throughout Israel's wanderings - giving instructions, providing direction, food, water and security. ${ }^{13}$

Therefore, based on Yahweh's most significant role and control of the events at the פי- which point to the fact that Yahweh fought for and delivered Israel; of the complete focus of the שִׁירָ on his praise; of the narrators recurrent reference to his name; and even of the Egyptian's acknowledgement that Yahweh made things happen for Israel, we submit that Israel's identity is rooted in Yahweh, the God of Israel. Without Yahweh, there was no crossing, without Yahweh, there was no victory and without Yahweh, there was no nation. Israel's distinct identity as a nation was from Yahweh (cf. Exod 11:7). They were called Yahweh's people (cf. 15:16) because their identity was formed and confirmed in Yahweh. Consequently, it is possible to extrapolate from this understanding that Israel's identity is a theological one (cf. Dearman 1992:35).

\section{Origin-Migration Narratives and Identity - Summary and Reflections}

The Yorùbá narratives examined above contain certain features which represent factors of identity formation among the people. These peculiar features include, primarily, a common

13 Indeed, the certainty of Yahweh's role in the life of Israel is not confined to the book of Exodus. The entire Hebrew Bible seems to reflect this precedence. Brueggeman (1997) demonstrates with copious data from the Hebrew Bible, that Yahweh is at the centre of the Israelite world and rhetoric. He claims that, "Yahweh is taken to be an accepted, unquestioned and indispensably key character in Israel's rendering of reality... Indeed, the reference to Yahweh cannot be removed from the rhetoric without the disintegration of Israel's testimony. Without Yahweh, Israel has nothing to say and no subject about which to speak... Therefore, Israel must, in giving account of its life, always refer to Yahweh" (1997:132). 
ancestry and ancestral home, a common language and a common belief in God. The ancestral home, Ilé-Ifẹ has its foundation in the people's origin myths and the migration theories.

The similarities and the peculiarities in what constitute features of identity formation and recognition in these narratives seem to attest to the multidimensional and fluid character of identity, especially of collective identity. Even though the children of Israel also claim a common ancestor ${ }^{14}$ like the Yorùbá, it is of interest to note other shared features in the stories of the people such as migration, crossing some great river and a common ancestor which in the case of Israel is Yahweh.

Moreover, the Yorùbá contended in battle with aborigines in the land but Israel's engagement in battle in the Sea Crossing was in an indirect way - in the context of a Holy War. Although the people were armed for battle when leaving Egypt, they did not use those arms - it was Yahweh who fought for his people. The Yorùbá narratives therefore can be deemed to foreground the role of Yahweh as Divine Warrior in the Sea event in the sense that while other nations ${ }^{15}$ fight for themselves to establish an identity, Yahweh fought for his own people. The Yorùbá narratives of origin and migration help to appreciate Yahweh's role more clearly and why he is so central to Israel's self-understanding. They offer fresh insight into the book of Exodus with respect to Israelite identity in that they help to foreground the inimitable role of Yahweh in the Sea event and to show him as the source of this identity.

Although in the history of its interpretation Exodus is traditionally read as a liberation text, we have attempted to show that the text is rich enough to accommodate other readings that are non-liberationist in focus. Therefore, the reading from the perspective of Israel's identity does not negate or invalidate the liberationist reading.

To sum up, migration is not just an ancient but also a global phenomenon. Human beings have been moving from one place to another since pre-historic times and will continue to do so, whether as individuals, families or groups. There is need to accept this human trait as inevitable as far as the social or global web is concerned. For this reason, the necessity for mutual acceptance and hospitality cannot be ignored whether on national or international levels. This is especially crucial in multi-racial and multi-ethnic contexts where there is a tendency to get 'territorial' and treat migrants as the other without full rights or claims as the supposed 'owners' of the land. More importantly, if it can be recalled that one's own ancestors were former migrants or aliens in the land where ownership is being claimed, then the words of Yahweh to Israel (Deut 4:34-38; 15:15; 16:11-12) to remember that they were slaves in Egypt and a migrant people would take on a new meaning.

Finally, a question that comes to mind is: Why do a people struggle to carve out an identity for themselves? Is this based on just a desire to be different and to stand out from the other? In our judgement, the struggle for identity is primarily a struggle for the resources of the earth. Every people, every nation, wants a part. The claim to a particular land or resource would seem to require some form of legitimation or the other. It would therefore appear logical to claim rights to a particular resource of the earth because of your connection to the owner. If a people claim descent from the Supreme Creator or have their identity rooted in him, surely it would not be out of place to claim a right of ownership with

14 That is, Abraham, but the point is not discussed in this essay.

15 See Olojede (2008) for accounts of battles by the Tiv of Central Nigeria and the amaZulu of South Africa. 
respect to his property! The same thing could apply to identities rooted in ancestors - "We are here because our ancestors left us this place as an inheritance".

Therefore, in as much as people would seek and continue to legitimize claims for their identity in their struggles for the earth's resources which in some cases appear not to go round, there would be a need to account for these resources in a responsible way. This should be especially so in situations where people claim affinity with God. The struggle for these resources should be carried out ethically and in the fear of this same God taking into account the dignity of every human being.

\section{BIBLIOGRAPHY}

Alter, R 2004. The Five Books of Moses: A Translation with Commentary. New York: WW Norton \& Co.

Amit, Y 2001. Reading Biblical Narratives: Literary Criticism and the Hebrew Bible. Minneapolis: Fortress.

Ashby G 1998. Exodus: Go out and Meet God. Grand Rapids: Eerdmans.

Awolalu O 1979 [1981]. Yoruba Beliefs and Sacrificial Rites. Essex: Longman.

Babatunde ED 1992. A Critical Study of Bini and Yoruba Value Systems of Nigeria in Change-Culture, Religion and the Self. New York: The Edwin Mellen Press.

Barber K 1991. I Could Speak until Tomorrow: Oriki, Women and the Past in a Yoruba Town. Edinburgh: Edinburgh University.

Beier U 1955a. Before Odùdùwà. Odu 3, 25-32. 1955b. The Historical and Psychological Significance of Yoruba Myths, in Biobaku \& Beier. The Use and Interpretation of Myths. Odu 1, 17-25.

Biobaku SO 1955a. Origins of the Yoruba. Lagos: Federal Ministry of Information Service. 1955b. Myths and Oral History, in SO Biobaku \& U Beier. The Use and Interpretation of Myths. Odu 1, 12-17.

Bosman HL 2005. Origin and Identity: Rereading Exodus as a Polemical Narrative; Then (Palestine) and Now (Africa). Scriptura, 90, 869-877.

Bowen TJ 1857 [1968]. Adventures and Missionary Labours in Several Countries in the Interior of Africa from 1849-1856. London: Frank Cass.

Brueggemann W 1997. Theology of the Old Testament: Testimony, Dispute and Advocacy. Minneapolis: Fortress.

2005. The Book of Exodus, in LE Keck (ed.). The New Interpreter's Bible: Old Testament Survey. Nashville: Abingdon.

Capozza D \& Brown R (eds.) 2000. Social Identity Processes. London: Sage Publications.

Castells M 1997 [2004]. The Power of Identity - The Information Age: Economy, Society and Culture. Vol. 2. Malden, MA: Blackwell.

Childs BS 1970. A Tradition-Historical Study of the Reed Sea Tradition. VT, 20/4, 406-418.

1977. Exodus: A Commentary. London: SMC.

Coats GW 1969. The Song of the Sea. $C B Q, 31 / 1,1-17$.

Dozeman TB 1996. God at War: Power in the Exodus Tradition. London: Oxford. 
2009. Commentary on Exodus. Grand Rapids: Eerdmans.

Drewal HJ et al 1989. Yoruba: Nine Centuries of African Art and Thought. NY:

Center for African Art.

Durham JI 1987. World Biblical Commentary Volume 3: Exodus. Waco, Texas: Word.

Farrow SS 1969 [1926]. Faith, Fancies and Fetish, or Yoruba Paganism. New York: Negro University Press.

Fischer G and Markl D 2009. Das Buch Exodus. Neuer Stuttgarter Kommentar Altes Testament. Stuttgart: Verlag Katholisches Bibelwerk.

Foerster W 1964 [1981]. From the Exile to Christ: Historical Introduction to Palestinian Judaism. Philadelphia: Fortress.

Fretheim TE 1990. Exodus: Interpretation - A Bible Commentary for Teaching and Preaching. Louisville: John Knox.

Frobenius L 1913. The Voice of Africa. 2 Volumes. London: Hutchinson.

Gnuse R 1999. Tradition History, in JH Hayes (ed.). Dictionary of Biblical Interpretation. Nashville: Abingdon, 583-588.

Gowan DE 1994. Theology in Exodus: Biblical Theology in the Form of a Commentary. Louisville: John Knox.

Houtman C 1996. Exodus. Volume 2. Kampen: KOK.

Idowu EB 1962. Olodumare: God in Yoruba Belief. London: Longmans.

Janzen JG 1992. Song of Moses, Song of Miriam: Who Is Seconding Whom? $C B Q, 54$, 211-220.

Johnson SC1921. The History of the Yorubas: From the Earliest Times to the Beginning of the British Protectorate. London: Routledge \& Paul.

Law RC 1973. Contemporary Written Sources, in SO Biobaku (ed.). Sources of Yoruba History. London: OUP, 9-24. 1977. The Oyo Empire (c.1600-1836). Oxford: Clarendon.

Lemche NP 1998. Prelude to Israel's Past: Background and Beginnings of Israelite History and Identity. Massachusetts: Hendrickson.

Lloyd PC 1955. Yoruba Myths: A Sociologist's Interpretation. Odu 2, 20-28.

Lucas JO 1948. The Religion of the Yorubas. Lagos.

Olojede, FO 2008. "The Exodus and Identity Formation in View of the Yoruba Origin and Migration Narratives”. Unpublished MTh Thesis. Stellenbosch: Stellenbosch University.

Olson DT 2010. Literary and Rhetorical Criticism, in TB Dozeman (ed.). Methods for Exodus. New York: CUP, 13-54.

Patterson RD 2004. Victory at Sea: Prose and Poetry in Exodus 14-15. Bibliotheca Sacra, 161, 42-54.

Pohl CD 1999. Making Room: Recovering Hospitality as a Christian Tradition. Grand Rapids: Eerdmans.

Propp WHC 1999. The Anchor Bible: Exodus 1-18 (A New Translation with Introduction and Commentary). New York: Doubleday.

Sarna NM 1991. The JPS Torah Commentary. Exodus. שִׁמוֹ The Traditional Hebrew Text with the New JPS Translation Commentary. Jerusalem: JPS. 
Steinberg, N 2010. Feminist Criticism, in TB Dozeman (ed.). Methods for Exodus. New York: CUP, 163-192.

Talbot PA 1926. The Peoples of Southern Nigeria. Volume 1. London: OUP.

Weitzman S 1997. Song and Story in Biblical Narrative: The History of a Literary Convention in Ancient Israel. Indianapolis: Indiana University Press.

Wescott RW 1957. Did the Yoruba Come from Egypt? Odu 4, 10-15.

Zornberg AG 2001. The Particulars of Rapture: Reflections on Exodus. New York: Doubleday. 